\section{Comparison of Paclobutrazol Drench and Spike Applications for Height Control of Potted Floriculture Crops}

\author{
James E. Barrett, Carolyn A. Bartuska, and Terril A. Nell \\ Environmental Horticulture Department, University of Florida, Gainesville, \\ FL 32611 \\ Additional index words. Caladium $\times$ hortulanum, Brassaia actinophylla, Euphorbia \\ pulcherrima, Impatiens wallerana, Bonzi, growth regulator
}

Abstract. Experiments with' White Christmas' and 'Carolyn Wharton' caladiums (Caladium $\times$ hortulanum Birdsey), croton (Codiaeum variegatum),brassaia (Brassaia actinophylla Endl.), 'Annette Hegg Dark Red' poinsettia (Euphorbia pulcherrima Wind.), and 'Super Elfin Red' and 'Show Stopper' impatiens [Impatiens wallerana (L.) Hook.f.] determined effectiveness of paclobutrazol in solid spike form as compared to media drench applications for height control. Paclobutrazol drenches and spikes were effective for all crops tested, with a similar concentration response for all, except that drenches had greater efficacy than spikes on caladium. A reduced effect was observed when spikes were placed on the medium surface of 'Super Elfin Red' impatiens, while placement in the middle of the pot or around the side was equally effective. These results indicate that the spike formulation of paclobutrazol has potential to provide adequate size control for floriculture crops with the possible exception of rapidly developing crops, such as caladiums. Chemical name used: (2RS, 3RS)-1-(4-chlorophenyl)-4,4-dimethyl-2- 1,2,4-triazol-1-yl-) penten-3-ol (paclobutrazol).

A problem with many growth retardants has been finding an efficient application method that produces consistent results. Spray applications are most commonly used in commercial practice, but can result in nonuniform plant size if proper techniques are not used, especially when applying the very active triazoles (Barrett and Nell, 1990; Barrett et al., 1994). Paclobutrazol provides size control on many floriculture crops (Barrett and Nell, 1989) and is active when applied to the growing media and taken up through the roots (Barrett and Bartuska, 1982; Davis et al., 1988).

Researchers have applied growth retardants as soaks to the root zone of rooted cuttings (Bearce and Singha, 1992) by impregnating chemicals into clay pots (Einert, 1976) and through irrigation water (Holcomb and White, 1970). Many solid forms of growth retardants,. such as capsules, gels, tablets (Sanderson et al., 1988), granules (Murray et al., 1986; Wilfret et al., 1978), and encapsulated slow-release materials (Read et al., 1974), have also been evaluated. The objective of our studies was to compare the efficacy of media drench and solid spike application methods of paclobutrazol on potted foliage and flowering plants.

Received for publication 7 June 1993. Accepted for publication 14 Sept. 1993. Florida Agricultural Journal Series no. R-03195. Funding for this research was provided by Uniroyal Chemical Co,, Florida Foliage Foundation, and Bates and Sons. The cost of publishing this paper was defrayed in part by the payment of page charges. Under postal regulations, this paper therefore must be hereby marked advertisement solely to indicate this fact.

\section{Materials and Methods}

Six experiments were conducted using plants from commercial growers. Except where specified, plants were grown in Vergro Klay Mix (Verlite Co., Tampa, Fla.) and treated at each irrigation with a $20 \mathrm{~N}-4.4 \mathrm{P}-16.6 \mathrm{~K}$ liquid fertilizer at a concentration of $150 \mathrm{mg} \mathrm{N} /$ liter. Experiments were arranged in randomized complete-block designs and included nontreated control plants.

Spikes were Jobe Fertilizer Spikes (Weatherly Consumer Products, Lexington, Ky.) without the fertilizer and with paclobutrazol incorporated. Concentration of paclobtrtrazol ranged from 0.0625 to $1.0 \mathrm{mg}$ a.i./spike. Unless otherwise indicated, spikes were pushed vertically into the medium until the top of the spike was even with the surface. Paclobtrtrazol drenches were applied using $120 \mathrm{ml}$ of growth regulator solution per 1.5-liter pot or $450 \mathrm{ml}$ per 4.4-liter hanging basket. Plant height was measured from pot rim to top of the foliage. Statistical analyses included analysis of variance, regression analysis, Tukey's honestly significant difference (HSD), and Dunnett's test (one-sided except where indicated).

\section{Results}

Croton, received as liners, were planted one plant per 1.5 -liter $(15-\mathrm{cm})$ pot and treated on 13 Dec. 1991 (Table 1). Plant height was measured at treatment and on 4 Feb. 1992, and results are expressed as change in height after treatment. The experiment had three replications with two plants per experimental unit.

Elongation of croton plants was reduced by paclobutrazol treatments compared to the con- trols. Concentration was a significant factor, but paclobutrazol form and the form $\mathrm{x}$ concentration interaction were nonsignificant variables (Table 1).

Brassaia were received as liners, planted one plant per 1.5-liter $(15-\mathrm{cm})$ pot on $22 \mathrm{Jan}$. 1988, and treated on 26 Apr. 1988 (Table 2). Stem length was measured at time of treatment and on 27 June 1988, and is shown as stem elongation after treatment. The design included five replications with one plant per experimental unit.

Stem elongation was affected by paclobutrazol concentration; elongation of plants receiving $5 \mathrm{mg}$ was $35 \%$ of elongation in plants treated with $1 \mathrm{mg}$ (Table 2). Paclobutrazol form and the form $\times$ concentration interaction were nonsignificant.

'Annette Hegg Dark Red'. poinsettia rooted cuttings were planted one per 1.5 -liter $(15-\mathrm{cm})$ pot on 9 Sept. 1991 and pinched on 26 Sept. Plants were grown under natural photoperiods, and fertilizer was at $300 \mathrm{mg} \mathrm{N} /$ liter. Paclobutrazol was applied 18 Oct. (Fig. 1), and plant height was measured 25 Nov. 1991. The experiment was in a completely randomized design with five replications.

Plant height decreased quadratically with increasing paclobutrazol concentration from the spikes (Fig. 1). No significant differences

Table 1. Effect of paclobutrazol form and concentration on croton height.

\begin{tabular}{|c|c|c|}
\hline \multicolumn{2}{|c|}{ Paclobutrazol } & \multirow{2}{*}{$\begin{array}{c}\text { Ht }(\mathrm{cm}) \\
\text { Change } \\
\text { from initial }\end{array}$} \\
\hline Form & $\begin{array}{c}\text { Concn } \\
\text { (mg a.i./pot) }\end{array}$ & \\
\hline Control & 0.00 & 9.5 \\
\hline \multirow[t]{2}{*}{ Drench } & 0.25 & 6.0 \\
\hline & 0.50 & 5.0 \\
\hline Spike, one $0.25-\mathrm{mg}$ & 0.25 & 6.0 \\
\hline two $0.25-\mathrm{mg}$ & 0.50 & 5.0 \\
\hline Dunnett' $s_{0.05}{ }^{y}$ & & 1.0 \\
\hline Dunnett's $s_{0.01}$ & & 1.5 \\
\hline \multicolumn{3}{|l|}{ Factorial analysis ${ }^{x}$} \\
\hline Form (F) & & NS \\
\hline Concentration (C) & & 0.0278 \\
\hline $\mathrm{F} \times \mathrm{C}$ & & NS \\
\hline
\end{tabular}

${ }^{2} 13$ Dec. to 4 Feb., 53 days.

"Comparison of control with other treatments.

"Excludes control.

${ }^{\mathrm{Ns}}$ Nonsignificant at $P \leq 0.05$.

Table 2. Effect of paclobutrazol form and concentration on Brassaia actinophylla stem elongation.

\begin{tabular}{|c|c|c|}
\hline \multicolumn{2}{|l|}{ Paclobutrazol } & \multirow{2}{*}{$\begin{array}{c}\text { Stem } \\
\text { elongation } \\
\text { (cm) }\end{array}$} \\
\hline Form & $\begin{array}{c}\text { Concn } \\
\text { (mg a.i./pot) }\end{array}$ & \\
\hline Control & 0.0 & 19.5 \\
\hline Drench & $\begin{array}{l}1.0 \\
5.0\end{array}$ & $\begin{array}{r}14.0 \\
5.5\end{array}$ \\
\hline Spike, four $0.25-\mathrm{mg}$ & $\begin{array}{l}5.0 \\
1.0\end{array}$ & $\begin{array}{r}5.5 \\
13.5\end{array}$ \\
\hline five $1.0-\mathrm{mg}$ & 5.0 & 4.0 \\
\hline Dunnett' $s_{0.05}$ & & 6.0 \\
\hline $\begin{array}{l}\text { Dunnett's } s_{0.01} \\
\text { Factorial analysis }\end{array}$ & & 8.0 \\
\hline Form $(\mathrm{F})$ & & NS \\
\hline Concentration (C) & & 0.0008 \\
\hline $\mathrm{F} \times \mathrm{C}$ & & NS \\
\hline
\end{tabular}

${ }^{2}$ Stem elongation was the change in height from time of treatment (26 Apr.) to 27 June 1988, 62 days.

${ }^{\mathrm{Ns}}$ Nonsignificant at $P<0.05$. 


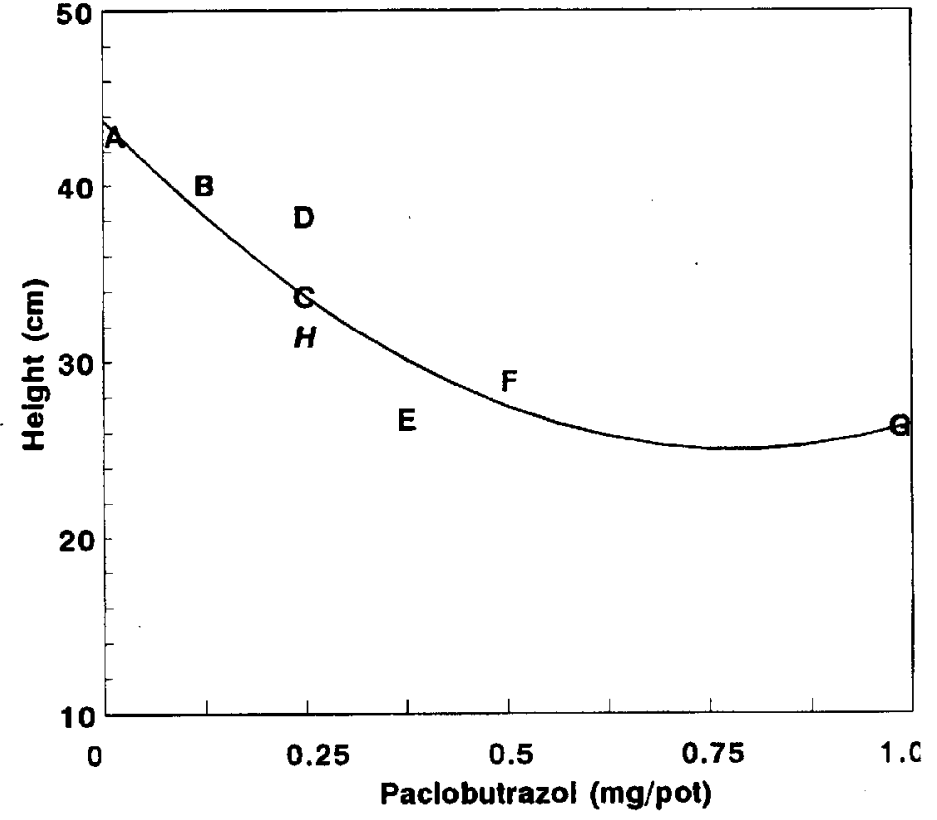

Fig. 1. Effect of paclobutrazol concentration when applied as a drench or spike on 'Annette Hegg Dark Red' poinsettia height. $\mathbf{A}=$ control; $\mathbf{B}=$ two $0.0625-\mathrm{mg}$ spikes; $\mathbf{C}=$ four $0.0625-\mathrm{mg}$ spikes; $\mathbf{D}=$ one $0.25-\mathrm{mg}$ spike; $\mathbf{E}=$ six $0.0625-\mathrm{mg}$ spikes; $\mathbf{F}=$ two $0.25-\mathrm{mg}$ spikes; $\mathbf{G}=$ one $1.0-\mathrm{mg}$ spike; and $\mathbf{H}=0.25 \mathrm{mg} / \mathrm{pot}$ drench. The concentration effect was quadratic at $\mathrm{P}=0.0009 ; \mathrm{y}=43.79-47.94(\mathrm{x})+30.65\left(\mathrm{x}^{2}\right) ; r^{2}=0.60$ $\mathrm{H}$ was not included in regression analysis; $\mathrm{n}=35$ for regression equation. Data points are the means for each treatment. Two-sided Dunnett's test indicated that H was not different from C and D.

in poinsettia height were evident for plants treated with one $0.25-\mathrm{mg}$ spike, four $0.0625-\mathrm{mg}$ spikes, or a $0.25-\mathrm{mg}$ drench.

'Show Stopper' impatiens seedlings were planted five per 4.4-liter $(25-\mathrm{cm})$ hanging basket on 19 Jan. 1988 and treated on 8 Mar. with one of three paclobutrazol drenches $(1,2$, or 4 $\mathrm{mg} / \mathrm{pot}$ ) or three spike treatments (four $0.25-\mathrm{mg}$, four $0.25-\mathrm{mg}$ and one $1-\mathrm{mg}$, or four 1-mg spikes; 1, 2, or $4 \mathrm{mg}$ a.i./pot, respectively). The design included five replications and two pots per experimental unit. Plant height and two widths were measured on 4 Apr. 1988, and plant size was calculated as the mean of height and width $\{h t+[(w 1+w 2) / 2] /$ 2].

Plant size was similar for pots given paclobutrazol as a drench or spike, and the form $\times$ concentration interaction was nonsignificant (results not shown). There was a negative linear correlation between plant size and concentration (Fig. 2).

'Super Elfin Red' impatiens seedlings were planted three per 1.5-liter $(15-\mathrm{cm})$ pot on 24 Jan. 1992 and were treated on 12 Mar. There were three paclobutrazol drench treatments $(0.5,1$, or $2 \mathrm{mg} / \mathrm{pot})$ and five spike treatments (one1-mg spike placed in the middle of the pot or placed on the surface; two $0.25-\mathrm{mg}$ spikes placed on two sides of the pot; four $0.25-\mathrm{mg}$ spikes placed one each on each of the four sides of the pot; or eight $0.25-\mathrm{mg}$ spikes placed evenly around the pot). The experiment included three replications and two pots per experimental unit. Plant size was determined on 3 Apr. 1992.

Plant size of 'Super Elfin Red' impatiens was reduced significantly by paclobutrazol drench or spike treatments with no form $\times$ concentration interaction, indicating a similar per experimental unit. Cultivar and cultivar $x$ form were nonsignificant factors. Paclobutrazol applications produced plants shorter than control plants; however, the drench applications had greater efficacy than did the spikes (Table 4).

\section{Discussion}

Our results demonstrate that efficacy of paclobutrazol in the form of spikes is similar to efficacy of drench applications for croton, $B$. actinophylla, poinsettia, and impatiens. Contrary to our results with spikes, Sanderson et al. (1988b) found greater efficacy for drench applications of paclobutrazol to chrysanthemums [Dendranthema $\times$ grandiflorum $(\mathrm{Ra}-$ mat.) Kitamura] than with gels, capsules, or tablets.

Spikes were not as effective as drenches on caladium (Table 4), which had the most rapid development rate of crops tested; the time from treatment to final data was only 3 weeks. Deneke and Keever (1992) compared drench and spike applications of paclobutrazol on tulips (Tulipa gesneriana L.), where the time from application to marketable stage was $<3$ weeks, and found a linear relationship between height and concentration for both forms. They did not, however, test for a form $\times$ concentration interaction nor for differences between the slopes, but the means they reported suggest that the response to increasing concentration was greater for drench applications than for spikes. Tulips given $0.06 \mathrm{mg}$ paclobutrazol were taller at flower color than those given $1.0 \mathrm{mg}$; the difference was $30 \%$ for drenches, but only $10 \%$ for spikes.

\section{Conclusions} three per 1.5-liter (15-cm) pot on 7 May 1992. Paclobutrazol was applied as a drench $(2.0$ $\mathrm{mg} / \mathrm{pot}$ ) or as two 1-mg spikes/pot on 21 May, and plant height was measured on 11 June. The design included five replications with two pots

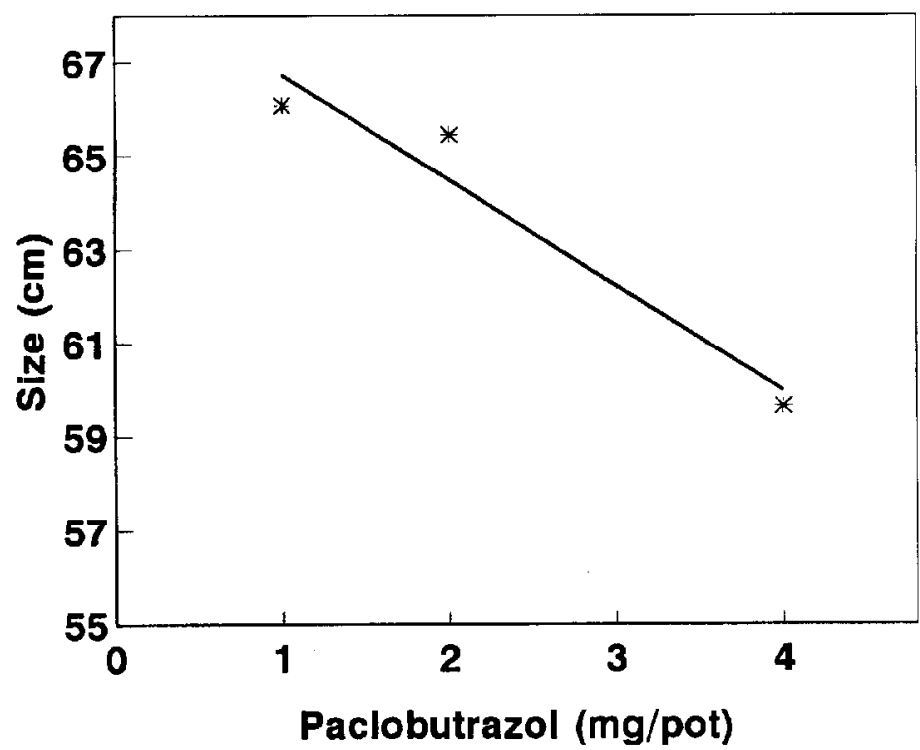

Fig. 2. Effect of paclobutrazol concentration on size of 4.4-liter hanging baskets of 'Show Stopper' impatiens; data pooled over form. Plant size was calculated as height plus width divided by 2 . Concentration significant at $P=0.0007 ; \mathrm{y}=68.98-2.25(\mathrm{x}) ; r^{2}=0.44$. Regression equation 'was generated with $n=30$. Data points are means for each treatment. 
Table 3. Effect of paclobutrazol form, concentration, and spike placement on 'Super Elfin Red' impatiens.

\begin{tabular}{|c|c|c|c|}
\hline \multicolumn{3}{|c|}{ Paclobutrazol } & \multirow[b]{2}{*}{$\begin{array}{c}\text { Plant } \\
\operatorname{size}^{z}(\mathrm{~cm})\end{array}$} \\
\hline Form & $\begin{array}{c}\text { Concn } \\
\text { (mg a.i./pot) }\end{array}$ & $\begin{array}{c}\text { Spike } \\
\text { location }\end{array}$ & \\
\hline Control & 0.0 & -- & 42.0 \\
\hline \multirow[t]{3}{*}{ Drench } & 0.5 & -- & 31.5 \\
\hline & 1.0 & -- & 30.0 \\
\hline & 2.0 & --- & 27.0 \\
\hline Spike, two 0.25-mg & 0.5 & Two sides & 32.5 \\
\hline four $0.25-\mathrm{mg}$ & 1.0 & Four sides & 30.5 \\
\hline one $1.0-\mathrm{mg}$ & 1.0 & Middle & 30.0 \\
\hline one $1.0-\mathrm{mg}$ & 1.0 & Surface & 33.5 \\
\hline eight $0.25-\mathrm{mg}$ & 2.0 & All around & 25.5 \\
\hline Dunnett's $\mathrm{s}_{0.05}{ }^{y}$ & & & 2.5 \\
\hline Dunnett's $s_{0.01}$ & & & 3.0 \\
\hline Location (spike $1 \mathrm{mg}$ & & & 0.0356 \\
\hline Form (F) (drench vs. & & & NS \\
\hline Concentration (C) $(0$ & or $2 \mathrm{mg} / \mathrm{pot}$ ) & & $0.0001^{\mathrm{w}}$ \\
\hline $\mathrm{F} \times \mathrm{C}$ & & & NS \\
\hline
\end{tabular}

Plant size was calculated as height plus width divided by 2, 22 days after treatment.

Comparison of control with other treatments.

${ }^{x}$ Spike location $\mathrm{HSD}_{0.05}=3.0$ for comparing those three means.

"Concentration effect was linear at $P=0.0001 ; \mathrm{y}=33.56-3.48(\mathrm{x}): r^{2}=0.72$.

${ }^{\mathrm{NS}}$ Nonsignificant.

the possible exception of the most rapidly developing species, such as caladium. Potential problems that may reduce the performance of spike formulations need to be explored. The importance of the active ingredient migrating to roots away from the spike and of uptake by roots close to or in contact with the spike is unknown. If used with subirrigation, the paclobutrazol may move upward and away from most of the root system. Also, if a single spike is placed on one side of a pot with multiple plants, the plants may grow unevenly due to differences in paclobtrtrazol uptake.

\section{Literature Cited}

Barrett, J.E. and C.A. Bartuska. 1982. PP333 effects on stem elongation dependent on site of application. HortScience 17:737-738.
Barrett, J.E., C.A. Bartuska, and T.A. Nell. 1994. Application techniques after uniconazole efficacy on chrysanthemums. HortScience (In press.)

Barrett, J.E. and T.A. Nell. 1989. Comparison of paclobutrazol and uniconazole on floriculture crops. Acts Hort. 251:275-280.

Barrett, J.E. and T.A. Nell. 1990. Factors affecting efficacy of paclobutrazol and uniconazole on petunia and chrysanthemum. Acta Hort. 272:229-234.

Bearce, B.C. and S. Singha. 1992. Response of poinsettia to preplant root-zone soaks in uniconazole. HortScience 27:1228.

Davis, T. D., F.L. Steffons, and N. Sankhla. 1988. Triazole plant growth regulators, p. 63-105. In: J. Janick (ed.). Hort. Rev. vol. 10. Timber Press, Portland, Ore.

Deneke, C.F. and G.J. Keever. 1992. Comparison of
Table 4. Effect of paclobutrazol drench and spike on 'White Christmas' and 'Carolyn Wharton' caladium height.'

\begin{tabular}{lc}
\hline Paclobutrazol & $\begin{array}{c}\text { Plant ht } \\
\text { (cm) }\end{array}$ \\
\hline form & 32.0 \\
Drentrol & 22.5 \\
Spike (two 1 mg spikes/pot) & 29.0 \\
HSD $_{0.05}$ & 2.5 \\
HSD $_{0.01}$ & 3.5 \\
\hline Cun $^{\prime}$ &
\end{tabular}

${ }^{2}$ Cultivar and cultivar $\times$ form were nonsignificant. Data pooled over cultivar. Measurement; 21 days after treatment.

application methods of paclobutrazol for height control of potted tulips. HortScience 27:1329.

Einert, A.E. 1976. Slow-release ancymidol for poinsettia by impregnation of clay pots. HortScience 11:374-375.

Holcomb, E.J. and J.W. White. 1970. A technique for soil application of growth retardant. HortScience 5:16-17.

Murray, G. E., K.C. Sanderson, and J.C. Williams. 1986. Application methods and rates of ancymidol on plant height and seed germination of bedding plants. HortScience 21:120122.

Read, P. E., V.L. Herman, and D.A. Heng. 1974. Slow-release chlormequat: A new concept in plant growth regulators. HortScience 9:55-57.

Sanderson, K. C., W.C. Martin, Jr., and J. McGuire. 1988. Comparison of paclobutrazol tablets, drenches, gels, capsules, and sprays on chrysanthemum growth. HortScience 23: 1008 1009.

Sanderson, K. C., W.C. Martin, Jr., and J. McGuire. 1990. New application methods for growth retardants to media for production of clerodendrum. HortScience 25:125.

Wilfret, G. J., B.K. Harbaugh, and T.A. Nell. 1978. Height control of pixie poinsettia with a granular formulation of ancymidol. HortScience 13:701-702. 